\title{
Uluslararası ticaret ve uluslararası turizm arasındaki ilişki: Türkiye örneği (1970-2019)
}

\section{The relationship between international trade and international tourism: The case of Turkey (1970-2019)}

\author{
Suna Şahin ${ }^{1}$
}

1 Dr. Öğr. Üyesi, İstanbul Yeni Yüzyıl Üniversitesi, İstanbul, Türkiye,

suna.sahin@yeniyuzyil.edu.tr

ORCID: 0000-0002- 8241-739X.

Başvuru/Submitted: 30/06/2021

Revizyon/Revised: 20/08/2021

Kabul/Accepted: 28/08/2021

Yayın/Online Published: 25/09/2021

Atıf/Citation: Şahin, S. Uluslararası ticaret ve uluslararası turizm arasındaki ilişki: Türkiye örneği (1970-2019), bmij (2021) 9 (3): 1060-1075, doi: https://doi.org/10.15295/bmij.v9i3.1876
Öz

Uluslararası turizm, küresel gelişme ve entegrasyon sürecinin bir parçası olarak, ekonominin büyümesine, ülkenin dünya pazarlarında rekabet gücünün artmasına ve nüfusun refahının artmasına bağlı olan etkili faktörlerden biri haline gelmiştir. Turizmin uluslararası, çok boyutlu bir olgu olması, dünya ülkelerinin sınırlarını açmasına neden olmaktadır. Bu çalışma turizmin ticaret üzerine yansımalarını ortaya koymayı amaçlamaktadır. Bu kapsamda Türkiye için 1970-2019 dönemine ait olarak elde edilen değişkenlere yönelik, birim kök, nedensellik ve eşbütünleşme analizleri yapılmıştır. Reel GSYIH, toplam ticaret (ihracat ve ithalat verileri), turizm verileri (turizm gelirleri ve gelen turist sayıları) kullanılarak yapılan analiz sonuçlarına göre Türkiye' de belirlenen dönemlerde uluslararası turizm, uluslararası ticaretin Granger nedenidir. Çalışma kapsamında bulunan sonuçların uzun dönemli olarak geçerliliği Engle-Granger Eşbütünleşme analizi yardımı ile sınanmış ve elde edilen ilşkinin uzun dönemde de geçerli olduğu sonucuna varılmıştır.

Anahtar Kelimeler: Uluslararası Ticaret, Küreselleşme, Uluslararası Turizm

Jel Kodları: F1, F5, F6

\begin{abstract}
As part of the global development and integration process, international tourism has become one of the influential factors that depend on the economy's growth, the increase in the country's competitiveness in world markets, and the increase in the population's welfare. Furthermore, tourism is an international and multidimensional phenomenon that causes countries to open their borders. Therefore, this study aims to reveal the reflections of tourism on trade. In this context, unit root, causality and cointegration analyzes were conducted for the variables obtained for the period 19702019 for Turkey. As a result, according to the analysis results using real GDP, total trade (export and import data), tourism data (tourism revenues and number of incoming tourists), international tourism is the Granger cause of international trade in Turkey in the specified periods. Furthermore, the longterm validity of the results within the scope of the study was tested with the help of Engle-Granger Co-integration analysis, and it was concluded that the obtained relationship was also valid in the long term.
\end{abstract}

Keywords: International Trade, Globalization, International Tourism

Jel Codes: F1, F5, F6 


\section{Extended Abstract}

The relationship between international trade and international tourism: The case of Turkey (19702019)

\section{Literature}

Kulendran and Wilson (2000) conducted the first research on the interdependencies between goods flows and tourist arrivals. Cointegration and Granger causality analyzes were applied by considering the variables of the holiday, business and total tourist arrivals, imports, and real exports for the 1982:1 - 1997:4 periods for Australia, USA, Japan, New Zealand and the United Kingdom. They used three hypotheses for this. The "Marco Polo" hypothesis is the interest and awareness hypothesis and the opportunity hypothesis. First, it indicates the existence of causality from business tourist inflows to trade. Second, he argues that trade leads to tourism (especially for holidays). Third, he argues that tourism for non-commercial purposes (holidays or visiting friends) can lead to commerce. The results showed that there is a bidirectional relationship between international trade and international tourism.

Shan and Wilson (2001) used GDP, total trade (both imports and exports), cost of living, exchange rate data variables to investigate the relationship between international trade and international tourism flows in China for the 1987:1-1998:1 periods. They applied the Granger causality test. The results show that there is bidirectional causality between trade and tourism in China.

In their study, Kadir and Jusoff (2010) considered tourism revenues, exports, imports and total trade data as variables within the scope of the 1995:1-2006:4 periods and conducted a study on Malaysia. Co-integration and causality tests were applied in the study, and a one-way causality was concluded from export and import flows to tourist inflows and from total trade to tourist inflows. According to the researchers, exports and imports in total trade cause growth in the tourism sector, indicating that most tourists are interested in business tourism.

Majewska and Mińska-Struzik (2012) investigated a relationship between tourists coming to Poland and Poland's export flows for the 1993-2010 and 2005-2010 periods. The study applied cointegration analysis, Granger causality and externality tests, and the Var Model was established. The cointegration analysis shows that export flows and inbound tourism generally show similar trends in the long run. In addition, the test of causality between exports and tourist arrivals showed that exports cause tourism more frequently.

Dritsakis and Athanasiadis (2000) examined some variables that affect tourist demand in Greece. In the econometric model used, it has been observed that disposable income does not significantly affect tourist demand. According to Dritsakis and Athanasiadis, this shows the conclusion that Greece continues to attract tourists even when incomes fall during recessions. The researchers stated that the average total cost and the cost of travel have minimal impact on tourist demand. It has been seen that the currency of the country of origin, namely the exchange rate, does not play an important role against the Greek drachma. On the other hand, advertising expenditures play an important role in tourist demand. Finally, the dummy variable, which measures the effect of political stability, showed that political stability is an essential factor in tourist demand.

In his study, Katırcıoğlu (2009) used GDP, tourist arrivals, trade volume, export and import variables for his research between international trade and international tourism and growth for Cyprus between 1960-2005. In the study, the ARDL Granger causality test was applied, and it was concluded that there is a causal relationship between growth and the number of tourists and between trade and the number of tourists.

Bahar and Baldemir (2008) researched Turkey using tourism revenues and export variables from 1980 to 2005 for the relationship between international trade and international tourism. Researchers have shown a one-way causality from tourism revenues to exports, and tourism movements between countries cause exports between the same countries.

Massidda and Mattana (2013) considered the relationship between international tourism and real GDP and the share of international commercial transactions in GDP for Italy for the 1987-2009 period. The variables are GDP, tourism revenues, total trade (exports and imports). According to the results, there is a long-term relationship between real GDP and international tourism, on the other hand, total trade and international tourism. Therefore, it is concluded that there is a one-way causality running from trade to tourism flow.

\section{Research subject}

This study aims to analyze the relationship between international trade and international tourism within the scope of the 19702019 periods in Turkey.

\section{Research purpose and importance}

Today, it is possible to state that the increase in international service trade continues rapidly, and tourism has the most critical place in traditional international service trade. Tourism is an international, multidimensional phenomenon with significant effects that cause countries to open their borders. In this study, the relationship between international trade and international tourism was investigated by using the variables of Real GDP, total trade (export and import data), tourism data (tourism revenues and incoming tourists) for the period 1970-2019 for Turkey, and the limited literature in the relevant field shows the importance of the study.

\section{Contribution of the article to the literature}

Although the relationship between international trade and economic growth has found wide application in the literature over the years, this cannot be said about tourism and the growth of trade and tourism. Therefore, this study will contribute to the literature.

\section{Design and method}

The study explains the relationship between international trade and international tourism through graphics, figures, and tables.

\section{Research type}

Research paper 


\section{Research problems}

Is there a relationship between Turkey's international trade and international tourism between 1970-2019 or not?

Data collection method

The data used in the study were obtained from TURKSTAT, the World Bank, the Ministry of Culture and Tourism and the Central Bank.

\section{Quantitative/qualitative analysis}

Granger causality analysis and Engle-Granger Co-integration analysis were applied for the relationship between international tourism and international trade in the specified periods in Turkey.

\section{Research hypotheses}

There is a relationship between international tourism and international trade in the specified periods in Turkey.

There is no relationship between international tourism and international trade in the specified periods in Turkey.

\section{Findings as a result of analysis}

According to the study results, international tourism is the Granger cause of international trade in the determined periods in Turkey. Therefore, it is concluded that there is a one-way causality running from total trade (import and export flows), tourist inflows and Real GDP to tourism income. Furthermore, the long-term validity of causality from total trade, real GDP and number of tourists to tourism revenues in the short-term was tested with the Engle-Granger cointegration test. As a result of the analysis, it was concluded that the series are cointegrated and move together in the long run.

\section{Hypothesis test results}

There is a relationship between international tourism and international trade in the specified periods in Turkey.

\section{Discussing the findings with the literature}

Although the relationship between international trade and economic growth has found wide application in the literature over the years, this cannot be said about tourism and the growth of trade and tourism. Therefore, this study will contribute to the literature. In this study, real GDP, total trade (export and import data), tourism data (tourism revenues and number of incoming tourists) variables are used for the relationship between international tourism and international trade for Turkey.

\section{Conclusion, recommendation and limitations}

Tourism can be seen as an intermediary factor in international relations globally because tourism can affect the world. Thanks to tourism, it will be possible to develop public diplomacy and economic relations internationally. The size of the tourism industry certainly depends on the policies of the governments, and the decisions taken by the governments for this industry will affect the relations with other countries because this industry plays a crucial role in economic growth and development, as well as political development and the expansion of peace. Therefore, Turkey needs to provide transportation facilities to attract tourists by using its ability to attract tourists due to its geographical location, strengthen its business policies with other countries by making international agreements, and take government decisions to increase its national and international activities. In short, barriers to international flows should be reduced or removed in a controlled manner. Therefore, it is possible to state that tourism revenues will be essential in solving Turkey's macroeconomic problems (balance of payments deficits). In addition, it has been observed that the share of tourism revenues in GDP, which can be considered an indicator of the importance of the Turkish economy in terms of growth, has increased and even in times of crisis, it has an income-providing income effect. Therefore, we can say that tourism is a vital trade activity for Turkey and contributes in many ways.

\section{Results of the article}

According to the study results, international tourism is the Granger cause of international trade in the determined periods in Turkey. The long-term validity of the results within the scope of the study was tested with the help of Engle-Granger Cointegration analysis, and it was concluded that there was a long-term relationship. In this study, it has been seen that there is a relationship between international trade and international tourism as a result of the analysis made using the variables determined for the period 1970-2019, which is the selected year range for Turkey (Real GDP, total trade and tourism data). According to the study results, international tourism is the Granger cause of international trade in the determined periods in Turkey. The long-term validity of the results within the scope of the study was tested with the help of Engle-Granger Cointegration analysis, and it was concluded that there was a long-term relationship. Considering the number of tourists coming to Turkey, it is possible to say that the country successfully attracts tourists, as can be seen in the graphs shown in the study. Therefore, it is possible to see Turkey as a tourism country.

\section{Suggestions based on results}

As part of the global development and integration process, international tourism has become one of the influential factors that depend on the economy's growth, the increase in the country's competitiveness in world markets, and the increase in the population's welfare. Tourism has an important place in integrating communities and countries into the global market economy. Most countries in the world are now making their cultures, societies and natural environments available to tourists. Due to socioeconomic changes in more developed countries, international tourism in less developed countries has become an attractive option for economic development. Despite the great economic importance of international tourism, as international tourism continues to grow, it is possible to see that there will be a series of adverse and positive effects. Globalization and international tourism growth can lower the domestic price level and increase foreign trade and the availability of products in the domestic economy, thereby stimulating more production. From this point of view, tourism has a significant share in the economic recovery of countries. However, it would be a grave mistake to treat all foreign visitors homogeneously when designing any policy to attract them to tourism activities. In other words, a successful promotional policy for any destination requires an in-depth study of the characteristics of visitors from various backgrounds and the destination itself. Therefore, more data on potential supply-side variables are needed if the international tourism determinants are better understood. Only in this way can more meaningful policy results be achieved. It is also essential that tourism is sustainable for a country. Tourism contributes more to the world than supporting economies and providing employment opportunities. 


\section{Giriş}

Küreselleşme çatısı altında ülkeler biribirine daha bağımlı hale gelmiştir. Küreselleşme ile birlikte bilgi teknolojisi alanında yaşanan gelişmeler dünyada ekonomik devrimlerin yaşanmasına neden olmuştur. $\mathrm{Bu}$ gelişmelerle birlikte hem yurtiçi ekonomiler hem de uluslararası ticaret alanında hizmetler sektörünün önemi hızlı artmıştır. Ancak gelişmiş ya da az gelişmiş ülkelerin bütününde hizmet sektörünün önemi yeterince anlaşılmış değildir

Klasik Ekolün kurucu olan Adam Smith, hizmetleri ekonomide birer kısır faaliyet alanı olarak nitelendirmiştir. Hizmetlerin ikinci derecede faaliyet alanı olarak görülmesinde geleneksel inancın etkisinin büyük olduğunu söylemek mümkündür. Ancak günümüzde teknolojide, telekomünikasyon (bilgisayar ve iletişim) teknolojilerindeki gelişmeler hizmetlerle ilgili geleneksel düşüncelerin hızla değişmesine neden olmuştur. Uluslararası turizm, birçok ülke için birincil değeri ve önemi olan bir ekonomik faaliyet olarak herkes tarafından kabul edilen bir gerçektir. Gelişmekte olan ülkeler, özellikle turizmi, potansiyel olarak ihtiyaçlarını döviz cinsinden karşılayabilecek bir sektör olarak görmüşlerdir. Günümüzde turizm, uluslararası ölçekte çok çeşitli ekonomik ve sosyal faaliyetleri içermektedir. Bu durum her modern toplumun gelişimi ile doğrudan ilişkilidir ve insanlık için daha iyi bir geleceğe ulaşmak adına farklı halklar arasında anlayış ve birlikteliği ilerletme koşullarını sağlamak önem arz etmektedir. Günümüzde ekonomik rekabet tüm dünyaya yayılmıştır. Bugün dünyadaki neredeyse tüm ülkeler kendilerini küresel ekonominin yapısal zorluklarına adapte etmeye çalışmakta ve küresel değişim çerçevesinde ekonomik hareketliliğin etkilerinden faydalanmak istemektedir. Ekonomik ve kültürel üretim süreçleri küreselleşme perspektifiyle, ülkeler arasındaki zaman, mekan, uzaklık ve yakınlık kavramlarını hızla etkilemiştir. Küreselleşmenin kolaylaştırıcılarından biri olan turizm, kapitalist sürecin yanında merkezden çevre katmanlara doğru hareket eden küresel ekonomik ağın mantığı içindeki akışlardan biri olarak değerlendirilmektedir. Küreselleşme çatısı altında özellikle gelişmiş bir kültürde insan ihtiyaçlarını optimum düzeyde karşılamak amaçlanmaktadır. İnsan ihtiyaçlarının karşılanmasına ilaveten ülkeler arasındaki ilişkilerin güçlendirilmesi ve ülkelerin turizm faaliyetleri ile ekonomilerini iyileştirme çabalarıda günümüzde hızla artmaktadır.

\section{Literatür taraması}

Turizm tahminiyle ilgili güncel literatür, uluslararası ticaretin uluslararası turizm akışlarını etkilemede oynadığı role işaret etmektedir. Turist talebinin belirleyicilerinden biri olarak uluslararası ticaretin oynadığı rol yeterince anlaşılmış değildir. Uluslararası turizm, daha fazla ticaret fırsatını tetikleyebilir ve dahası, iş seyahatleri 1980'lerden beri uluslararası turizmin önemli bir bileşeni olmuştur. Bu nedenle uluslararası turizm, uluslararası ticareti teşvik eder mi yoksa ticaret, turizmi teşvik eder mi? Bu sorunun dikkate alınmaması, turist talebi işlevinin belirleyicilerinin yetersiz değerlendirilmesine yol açmaktadır. (Shan ve Wilson, 2001: 279). Turizm, uluslararası mal akışını teşvik edebilir ve diğer yandan ticaret turizmi canlandırabilir.

Ticaret ve turizm arasındaki bağlantının teorik gerekçesini sunabilecek mikroekonomik bir model hala bulunmasa da seçilen ülkelerde geliştirilen ampirik çalışmalar, tartışılan karşılıklı ilişkilerin gerçekten var olduğunu göstermektedir (Majewska ve Mińska-Struzik, 2012:2). Uluslararası turizm talebi genellikle bir menşe ülkeden yabancı bir istikamete gelen turist sayısı veya bir varış ülkesindeki turistlerin yaptığı harcamalar açısından ölçülür (Lim ve Mcaleer, 2000:500). Çoğu ülkede ulusal gelirin devam eden büyümesi buna ilaveten ulaşım maliyetlerindeki önemli düşüş, sınır ötesi hareketlerin serbestleşmesi ve yurtdışına seyahat etme eğiliminin artmasıyla birlikte, dünyadaki toplam uluslararası ziyaretçi sayısı artmıştır.

Ampirik olarak, turizm talebini modellemek için iki ana yaklaşım vardır (Wang ve $\mathrm{Wu}, 2003: 321)$ : Tek denklem yaklaşımı ve eşzamanlı denklem yaklaşımı. Tek denklemli yaklaşım, turizm talebinin turist harcamaları (gelirler) veya turistlerin gelen sayısı ile ölçüldüğünü, gelire, göreli fiyatlara veya döviz kurlarına ve ulaşım maliyetlerine ve ayrıca pazarlama harcamaları, politik aksaklıklar veya önemli spor etkinlikleri gibi diğer faktörlere bağlı olduğunu varsayar. Eşzamanlı denklem yaklaşımı ise ekonomik birimlerin yabancı turizme harcanacak miktarı önceden belirlediklerini ve ardından hedef ülkelerin uluslararası turizm bütçesindeki payının duyarlılığını özellikle farklı istikametler arasındaki gelir ve göreceli fiyatlardaki değişikliklere göre tahmin ettiğini varsayar. Eşzamanlı denklem yaklaşımı, bir ekonominin uluslararası turizm piyasasındaki göreceli rekabet gücünün araştırılmasında daha uygun görülebilir. Göreceli fiyat etkisi, ziyaretin amaçlarına ve seyahat kalıplarına bağlıdır; döviz kuru etkisi, varılan ülkedeki turizm harcamalarının yerel para birimi cinsinden mi yoksa menşe ülkenin para birimi cinsinden mi fiyatlandırıldığına bağlıdır ve arz eğrisi etkileri başlangıç ve varış noktasına bağımlıdır (Wang ve $\mathrm{Wu}, 2003: 341)$. 
Ticaret-turizm literatürünün gözden geçirilmesi, iki akış arasındaki ilişkinin doğası ve gücünün daha fazla araştırılması için bir mantık sağlamaktadır. Araştırma metodolojisi açısından, en yaygın yöntemler eşbütünleşme analizi ve Granger nedensellik testleridir. Ticaret ve turizm arasındaki ilişkiyi neyin belirlediğini ve ticaret ve turizmin belirleyicilerinin iki akış arasındaki nedenselliğin varlığını etkileyip etkilemediğini test etmek için bazı kontrol değişkenleri modellere dahil edilmelidir (Fry, Saayman ve Saayman, 2010).

Kulendran ve Wilson (2000) mal akışı ile turist girişleri arasındaki karşılıklı bağımlılıklara ilişkin ilk araştırma yapmışlardır. Avustralya, ABD, Japonya, Yeni Zelanda ve Birleşik Krallık için 1982:1- 1997:4 dönemlerine ait tatil, iş ve toplam turist gelişleri, ithalat, reel ihracat verilerini değişkenlerini ele alarak eşbütünleşme ve Granger nedensellik analizlerini uygulamışlardır. Bunun için üç hipotez kullanmışlardır. Bu hipotezler; "Marco Polo" hipotezi, ilgi ve farkındalık hipotezi ve fırsat hipotezidir. Birincisi, iş amaçlı turist girişlerinden ticarete nedenselliğin varlığına işaret etmektedir. İkincisi, ticaretin turizme yol açtığını (özellikle tatiller için) iddia etmektedir. Üçüncüsü, ticari olmayan amaçlarla yapılan turizmin (tatiller veya arkadaş ziyaretleri için olduğu gibi) ticarete yol açabileceğini savunmaktadır. Sonuçlar uluslararası ticaret ve uluslararası turizm arasında çift yönlü ilişki olduğunu göstermiştir.

Shan ve Wilson (2001), 1987:1-1998:1 dönemleri için Çin' deki uluslararası ticaret ve uluslararası turizm akışları arasındaki ilişkiyi araştırmak adına GSYIH, toplam ticaret (hem ithalat hem ihracat), yaşam maliyeti, döviz kuru verileri değişkenlerini kullanmışlar ve Granger nedensellik testini uygulamışlardır. Sonuçlarda Çin'de ticaret ve turizm arasında çift yönlü bir nedensellik olduğunu tespit etmişlerdir.

Kadir ve Jusoff (2010) çalışmalarında, 1995:1-2006:4 dönemleri kapsamında turizm gelirleri, ihracatı, ithalatı ve toplam ticaret verilerini değişken olarak ele almışlar ve Malezya üzerinde çalışma yapmışlardır. Çalışmada eş bütünleşme ve nedensellik testleri uygulanmış, ihracat ve ithalat akışlarından turist girişlerine ve toplam ticaretten turist girişlerine kadar uzanan tek yönlü bir nedensellik sonucuna varılmıştır. Araştırmacılara göre, toplam ticarette ihracat ve ithalat turizm sektöründe büyümeye neden olmaktadır ve bu da turistlerin çoğunun iş turizmi ile ilgilendiğini göstermektedir.

Majewska ve Mińska-Struzik (2012) çalışmalarında, 1993-2010 ve 2005-2010 dönemleri için Polonya'ya gelen turistler ile Polonya'nın ihracat akışları arasındaki ilişkinin varlığını araştırmışlardır. Çalışmada eşbütünleşme analizi, granger nedensellik ve dişsallık testleri uygulanmış, Var Modeli kurulmuştur. Eşbütünleşme analizi, uzun vadede ihracat akışlarının ve gelen turizmin genel olarak benzer eğilimler gösterdiğini göstermektedir. Buna ilaveten ihracat ve turist gelişleri arasındaki nedenselliğin testi ihracatın turizme daha sık neden olduğunu göstermiştir.

Dritsakis ve Athanasiadis (2000) çalışmalarında, Yunanistan'da turist talebini etkileyen bazı değişkenleri incelemişlerdir. Kullanılan ekonometrik modelde, harcanabilir gelirin, turist talebi üzerinde önemli bir etki yapmadığı görülmüştür. Bu, ekonomik durgunluk dönemlerinde gelirleri düştüğünde bile Yunanistan'ın turist çekmeye devam ettiği anlamına geldiği sonucunu göstermektedir. Araştırmacılar, ortalama toplam maliyetin ve seyahat maliyetinin turist talebi üzerinde minimum etkiye sahip olduğunu belirtmişlerdir. Yunan drahmi karşısında menşe ülkenin para biriminin yani döviz kurunun önemli bir rol oynamadığı görülmüştür. Reklam harcamaları, turist talebinde önemli bir rol oynamaktadır. Siyasi istikrarın etkisini ölçen kukla değişken, turist talebinde siyasi istikrarın önemli bir faktör olduğunu göstermiştir.

Katırcıŏ̆lu (2009) çalışmasında, Kıbrıs için 1960-2005 yılları arasında uluslararası ticaret ve uluslararası turizm ve büyüme arasındaki araştırması için GSYİH, turist gelişleri, ticaret hacmi, ihracat ve ithalat değişkenlerini kullanmıştır. Çalışmada ARDL Granger nedensellik testi uygulanmış ve büyüme ve gelen turist sayısı arasında ve de ticaret ile gelen turist sayısı arasında nedensellik ilişkinin olduğu sonucuna varılmıştır.

Bahar ve Baldemir (2008) çalışmalarında, uluslararası ticaret ile uluslararası turizm arasındaki ilişki için 1980-2005 dönemlerine ait turizm gelirleri ve ihracat değişkenlerini kullanarak Türkiye üzerine araştırma yapmışlardır. Araştırmacılar, turizm gelirlerinden ihracata tek yönlü bir nedenselliğin ve ülkeler arasında meydana gelen turizm hareketlerinin yine ayn ülkeler arasında ihracata neden olduğunu göstermiştir.

Massidda and Mattana (2013) çalışmalarında 1987-2009 dönemleri kapsamında İtalya için, uluslararası turizm ve reel GSYİH arasındaki ilişki ve uluslararası ticari işlemlerin GSYİH içindeki payını dikkate almışlardır. Değişkenler, GSYİH, turizm gelirleri, toplam ticaret (ihracat ve ithalat)dir. Sonuçlara göre, reel GSYIH ve uluslararası turizm, diğer yandan toplam ticaret ve uluslararası turizm arasında uzun 
vadeli ilişki söz konusudur. Ticaretten turizm akışına doğru giden tek yönlü bir nedensellik olduğu sonucuna varılmıştır.

Ozcan ve Yorgancılar (2016) çalışmalarında, Türkiye'yi örnek alarak uluslararası ticaret ve uluslararası turizm arasındaki ilişkiyi araştırmışlardır. 1963-2010 dönem aralığı için yapmış oldukları çalışmada Granger Nedensellik Testi ve TodaYamamoto yöntemlerini tercih etmişlerdir. Çalışmanın sonucunda, ihracat ve toplam ticaret hacmi ile turizm arasında çift yönlü, ithalat ile ise tek yönlü bir nedensellik ilişkisinin olduğunu ve turizmden tüm diğer değişkenlere doğru tek yönlü bir nedenselliğin olduğunu tespit etmişlerdir.

Ozcan (2016) çalışmasında 1995'ten 2013'e kadar 16 Akdeniz ülkesi için uluslararası ticaret ve turizm arasındaki nedensel ilişkiyi incelemektedir. Panel Granger nedensellik sonuçlarına göre on altı Akdeniz ekonomisinden dördünde ihracattan turizme doğru nedensellik bulunmaktadır.

\section{Dünya hizmetler ticareti içinde turizmin önemi}

Karşılaştırmalı Üstünlükler Teorisine göre üretim faktörleri ülke için tam hareketli iken ülkeler arasında tam hareketsizdir. Bu varsayım dolayısıyla Heckscher-Ohlin modelini hizmet ticaretinde uygulamak zordur. Bunun nedeni ise hizmet ticaretinin büyük ölçüde üretim faktörlerinin uluslararası alanda hareketliliğine bağlı olmasıdır. Ekonomik faaliyetler kapsamında hizmetler kesimi geniş bir alanı kapsamaktadır. Bu nedenlede sektörün genel bir tanımını yapmak güçtür. Bununla birlikte, üretimi ve tüketiminin aynı yerde ve eş anlı olarak gerçekleştirilmesi, diğer bir ifadeyle hizmeti sağlayan ile bundan yararlanan arasında dolaysız bir ilişki bulunması, hizmetlerin saklanamaması ve elle tutulamaz nitelikle olması bazı ortak özelliklerdir.

Hizmetler, teknoloji içeriklerine göre bilgiye dayalı olanlar ve geleneksel hizmetler olmak üzere iki sıraya ayrılmaktadır (Seyidoğlu, 2007: 790-791). İlk sıraya sigortacılık, bilgi teknolojisi, danışmanlık, müteahhitlik ve teknik hizmetler, reklamcılık, sağlık, eğitim, kamu hizmetleri vs. girmektedir. Bu hizmetleri yürütenler göreceli olarak yüksek bir beşerî sermayeye sahiptirler. İkinci sırada ise ise turizm, taşımacılık, sosyal hizmetler gibi yöntemleri içeren geleneksel faaliyetler yer almaktadır. Uluslararası ticarete giren geleneksel hizmet faaliyetlerinin başında turizm gelmektedir. Uluslararası turizm, sanayileşmeye destek sağlayan önemli sektörlerden birisidir. Aslında uluslararası turizm, döviz gelirlerini artırmak üzere, gelişmiş ve az gelişmiş ülkelerin yoğun biçimde özendirmeye çalıştıkları bir hizmet alanıdır. Artan küreselleşme olgusu, uluslararası turizmin önemli ölçüde büyümesi de dahil olmak üzere, uluslararası mal ve hizmet akışının sistematik olarak yoğunlaşmasıyla kendini göstermektedir. İhracatı artırmayı ve böylece küresel ekonomik bağlantılar ağına katılmayı hedefleyerek ekonomilerini açan ülkeler, genellikle turist girişlerinde bir artı̧̧ yaşarlar.

Doğal, tarihi ve kültürel zenginliklere sahip ülkeler turizm açısından göreceli bir üstünlüğe sahiptir. Bununla birlikte, turizmin geliştirilebilmesi aynı zamanda belirli bir alt yapının oluşturulmasını gerektirir. Bu açıdan ülkenin yatırım kaynakları tarım, sanayi ve benzeri sektörler arasında dağıtılırken turizm kesimine de gereken pay ayrılmalıdır (Seyidoğlu, 2007: 798). Turizm ülkede özellikle küu̧ük ve orta ölçekli işletmelerin geliştirilmesinde de önemli bir kaynak durumundadır. Turizim, kaynaklara göreceli bakımdan zengin biçimde sahip ülkelerde, gelir ve istihdam etkilerinin yanında ülkeye önemli ölçüde döviz geliri kazandırabilir. Elde edilen bu dövizler ise örneğin kalkınmakta olan bir ülkede sanayileşme çabalarına önemli destek oluşturur. Bu nedenlede gerekli alt yapıya sahip ülkelerde, bir yandan ihracatın özendirilmesine önem verilirken, diğer yandan da turizm gelirleri artırılmaya çalışılır.

Dünyadaki ülkeler için turizm endüstrisi, önemli ekonomik kazançlar sağlayan elverişli bir iş sektörü haline gelmiştir. Turizm endüstrisi, özellikle gelişmekte olan yerlerde, turizmle birlikte gelen istihdam ve ekonomik faaliyetlerin artırılması yoluyla yoksulluğun ve bölgesel eşitsizliklerin azaltılmasına yönelik hayati bir itici güçtür. Çoğu gelişmiş ve gelişmekte olan ülkede turizm endüstrisi hem imalat hem de tarım sektörlerini geride bırakarak temel bir gelir üreticisi olarak tanımlanmıştır (Hanafiah ve Zulkifly, 2019: 24). Genel ekonomik büyümenin turizm sektörünün genişlemesini sürdürdüğü ileri sürülmektedir (Massidda ve Mattana, 2013:93). Turist hareketlerini olumlu etkileyen ana değişken Gayri Safi Milli Hasıla'daki (GSMH) büyümedir. GSMH artışı harcanabilir geliri ve dolayısıyla çeşitli mal ve hizmetleri tüketme istekliliğini ve yeteneğini artırır. Turist sektörünün katkısı, döviz sektörü dışındaki sektörler üzerindeki etkisi nedeniyle bir ülke ekonomisi için faydalıdır. Bu faydalara aşağıdaki örnekler verilebilir (Dritsakis ve Athanasiadis, 2000: 1-2):

$>$ İstihdam sektörü ve özellikle de göç etme eğiliminin kısıtlanması ve nüfusun korunması,

> Sanayi ve ticaretin genişlemesi yoluyla iş sektörü, artan turist dalgasını karşılayacak tarımsal üretim, uluslararası ve iç ticaretin harekete geçirilmesi ve ulaştırma gibi hizmetlerle ilgili çeşitli sektörlerin faaliyetleri, telekomünikasyon, bankacilık, seyahat acenteleri vb. 
> Gelirler sektörü; Turist gelirinin ülkenin toplam gelirine katkıda bulunması,

> Kültür sektörü; Turizmin arttığı bölgelerde yaşam standartlarının iyileştirilmesinin yanı sıra kültürel standartlarda da önemli iyileşmelerin olması,

> Mali sektör; Turist faaliyetinin kamu ekonomisi ve özellikle yerel düzeyde faydalı sonuçlar vermesidir.

> Turist ziyaretleri, yaş, coğrafi çeşitlilik için algılanan ihtiyaç, yabancı dilde akıcılık gibi özellikler birleştirildiğinde, ülkelerin ticaret üzerinde turizmin etkisi daha büyük olabilir (Aradhyula ve Tronstad,2003: 569). Turizm, ulaşım ve altyapı, konaklama, yiyecek ve içecek işletmeleri gibi turizm tesisleri ve destek hizmetleri gibi birçok bileşeni olan çok yönlü bir endüstridir. Hem özel hem de kamu sektörleri bu sektörde yer almaktadır (Luca ,1997:20).

Turizm üç tür iş veya ticaret içermektedir. Bunlar (Berno ve Bricker, 2001: 6)

- En yaygin olarak turizmle ilişkilendirilen birincil ticaretler (örneğin, ulaşım, tur şirketleri, seyahat acenteleri, konaklama, catering tesisleri ve turistik yerler);

- Turizme özel olmasa da turizmi desteklemeye yardımcı olan ikincil ticaretler (örneğin, perakende alışveriş, bankalar ve sigorta, eğlence ve boş zaman etkinlikleri, kişisel hizmetler); ve turizm için temel altyapı ve desteği sağlayan üçüncül ticaretler (örneğin, kamu sektörü hizmetleri, gida ve yakıt, imalat).

\section{Türkiye'de turizmin seyri}

21. yüzyılın başında turizm, günümüzün küresel olgusuna dönüşerek ekonomik kalkınmanın güçlü bir bileşeni ve dünyanın birçok ülkesinin imajını şekillendirmede bir faktör haline gelmiştir (Kyrylov ve diğerleri,2020:2). Uluslararası hizmetler içerisinde en fazla olan şey turizmdir. Kitle turizminin, gelişmekte olan ve gelişmiş ülkeler üzerinde hem olumlu hem de olumsuz olarak büyük ekonomik, sosyal ve kültürel etkileri vardır. Turizmin ekonomik etkileri dış ticaret, cari açık, turizm geliri ve arz kapasitesi gibi makro düzeyde gerçekleşirken, turizmin sosyal etkileri mikro düzeyde gerçekleşmekte ve toplumsal refahta daha dolaylı faydalar üretmektedir (Ozcan ve Ozcan, 2020: 1). Döviz gelirlerinin neredeyse tamamına yakınını turizmden sağlayan ülkeler bulunmaktadır. Bu öneminden dolayı turizmden dumansız endüstri olarak da söz edilmektedir (Çelik, 2004:311). Bir ülkede yerleşik kişilerin yabancı ülkelerde yapmış oldukları turistik harcamaları hizmet ithalatı olarak değerlendirilmektedir. Türkiye, turizm açısından önemli ülkeler arasında yer almaktadır. 1923 yılında Reşit Saffet Atabinen tarafından Mustafa Kemal Atatürk'ün direktifleriyle kurulan Türk Seyyahin Cemiyeti ile Türkiye'de turizme yönelik ciddi anlamda turizm çalışmaları başlamıştır. Cemiyet, 1926 yılında adını "Türkiye Turing Klubü "ve 1930 yılından itibaren ise "Türkiye Turing ve Otomobil Kurumu" olarak değiştirmiştir (Altıntaş ve Şahin, 2007: 18-19). 1960 yılında T.C. Turizm Bankası kurulmuş, 1962 yılında da faaliyete girmiştir (Önen, 2000). Ülkelerin içinde bulundukları siyasi ve ekonomik dalgalanmalar uluslararası ziyaretçi sayılarını etkileyebilir. Nitekim Türkiye'de de yaşanan siyasi durumlar neticesinde bazı yıllarda, örneğin 1960'lı, yıllarda uluslararası ziyaretçi sayısı azalma göstermiştir.1970'li yıllarda Türkiye'de turizmle ilgili ilk devlet planlamaları yapılmış ancak planlamalar ya bölgesel düzeyde kalmış ya da birçoğu uygulanamadığı için 1980'li yıllara kadar Türkiye, turizmde beklenilen gelişimi sağlayamamıştır. 24 Ocak 1980 kararları ile Türkiye yeni bir döneme girmiş ve piyasalara müdahaleler azaltılarak liberalizasyon süreci başlamıştır. 1980 öncesi Türkiye'nin yaşadığı ihracat problemi, döviz darboğazları, ticaret engelleri gibi birçok ekonomik sorunu bulunmaktaydı. Dolayısıyla 24 Ocak 1980 kararları neticesinde bu sorunların çözümüne yönelik atılan adımlarda katkısı olacak sektörlere yatırımların artırılması gerekliydi. Hizmet ticareti kapsamında döviz girişini sağlayacak ve ülke için önemli bir ekonomik gösterge olan ödemeler dengesini iyileştirici etkisi olan turizmin geliştirilmesi önem arz etmekteydi. Dolayısıyla Türkiye'nin 24 Ocak 1980 kararları ile ihracata yönelik sanayileşme stratejisini benimsemesi diş turizmin aktifleşmesinde önemli bir gelişmedir (Kanca, 2015:4). Turizmin ülkeye olan yararı sadece ekonomik olarak düşünülmemeli ekonominin yanında aynı zamanda sosyal ve kültürel olarak da birçok katkısının olacağı unutulmamalıdır (Çoban ve Özcan, 2013:243). 1982 yılında yürürlüğe giren 2634 sayılı Turizm Teşvik Kanunu bugünki turizm sektörünün oluşmasında önemli olmuş ve bu kanunla turizm alan ve merkezleri belirlenmiştir (Toker, 2007: 83). Aşağıdaki Grafik 1'de 1969-2019 yılları kapsamında Türkiye'ye gelen turist sayıları gösterilmiştir. Türkiye'yi ziyaret eden uluslararası turist sayısı yıllar itibariyle artış göstermiştir. 


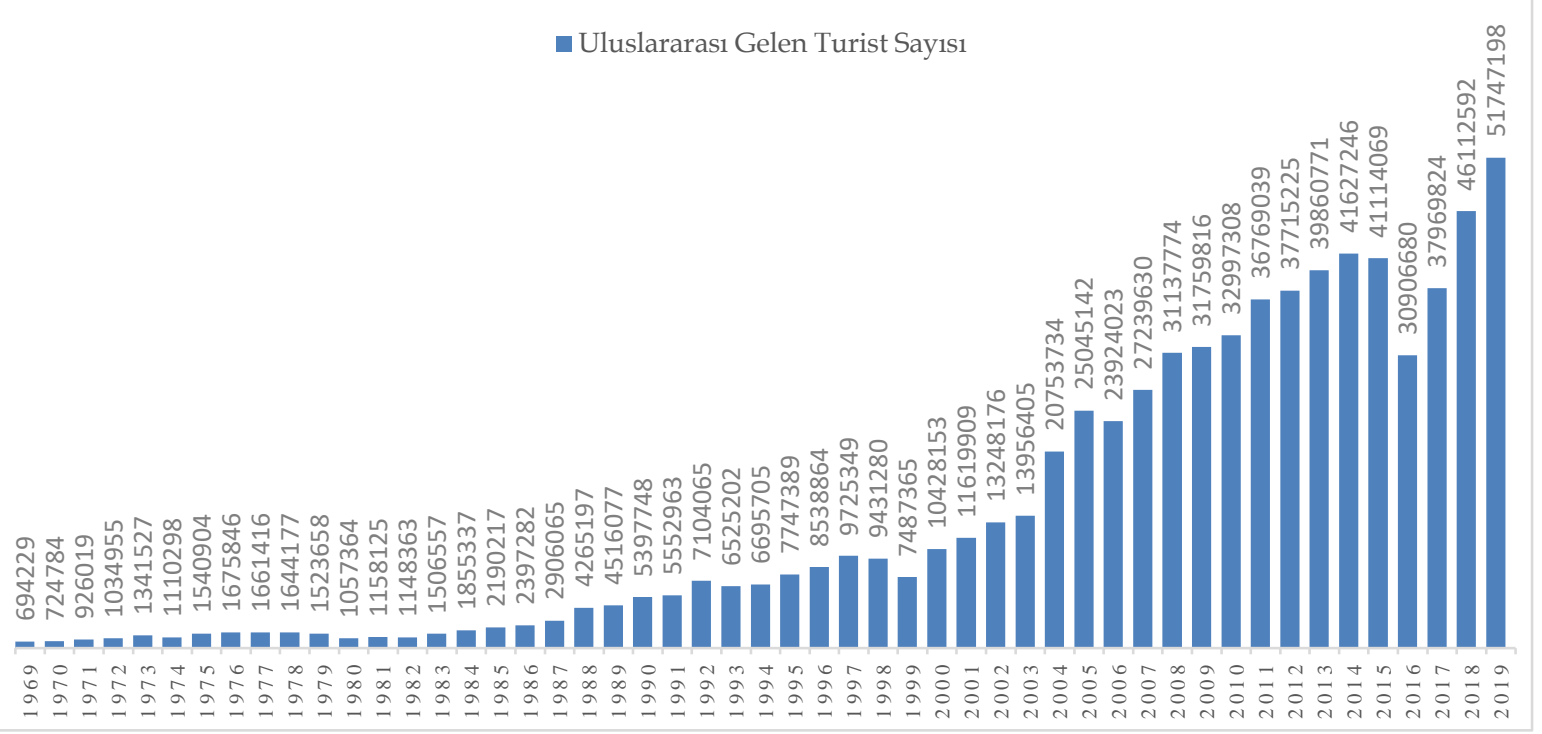

Grafik 1: Türkiye'ye 1969-2019 Yilları Arasında Gelen Uluslararası Turist Sayısı

Kaynak: "Turizm İstatistikleri", 2021, Yazar tarafından oluşturulmuştur.

1990-1991 yıllarında meydana gelen Körfez Savaşı́nın da Türkiye turizm sektörü üzerinde ciddi olumsuz etkileri olmuştur. Savaş bölgesine oldukça yakın olan Türkiye' nin 1990 yılında turizm gelirleri düşmüştür. Yine 1999 yılında meydana gelen Kocaeli Depremi ve 2008 yılında yaşanan küresel kriz sonucunda, turizmden elde edilen gelirler düşmüştür.

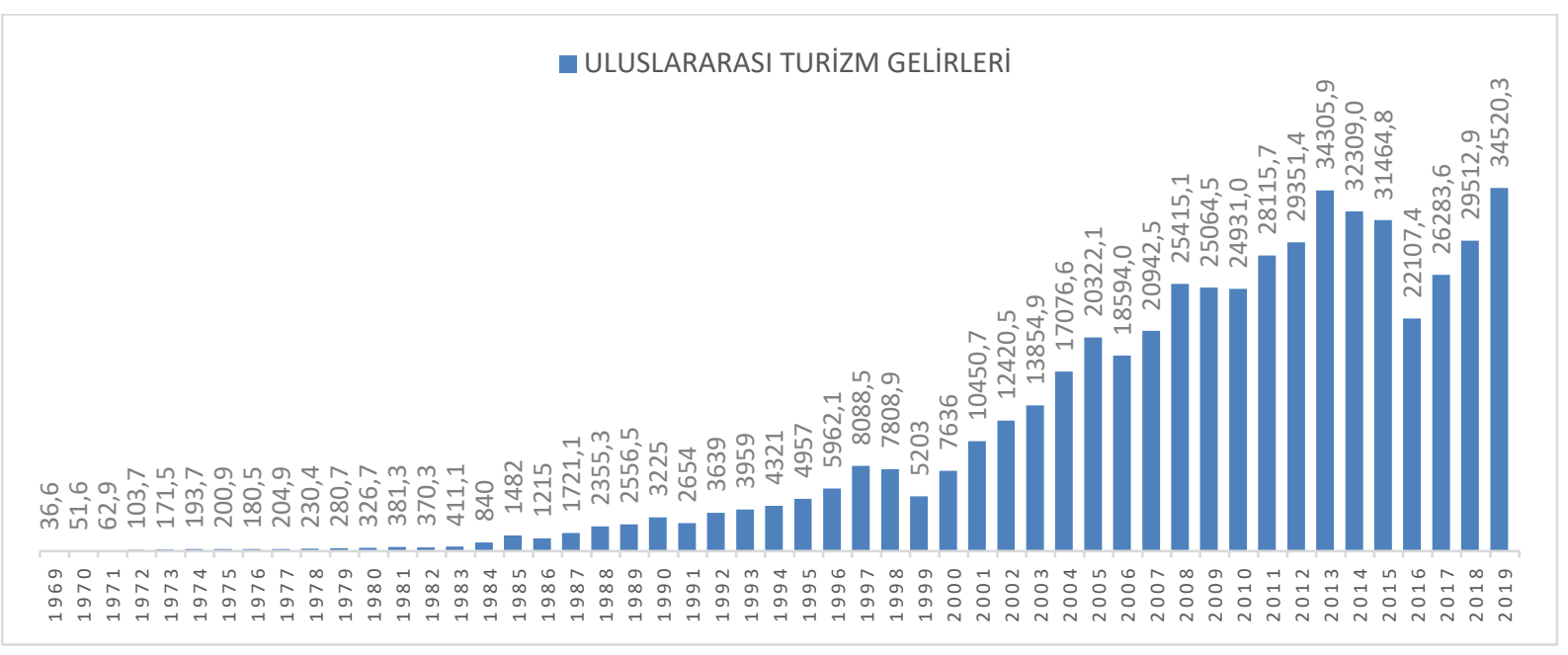

Grafik 2: Türkiye'nin 1969-2019 Yılları Uluslararası Turizm Gelirleri

Kaynak: "Turizm İstatistikleri", 2021,Yazar tarafından oluşturulmuştur.

Turizm sektörünün ekonomi üzerindeki etkisinin anlaşılabilmesi için toplam gelirlerin GSYİH içindeki payına da bakılması gerekmektedir. Turizm gelirlerinin GSYİH içindeki payı, bu sektörün ülke için ne kadar önemli olduğunu gösteren önemli bir parametredir. Turizmin ülkelerin ekonomilerine etki etmesi, turizmin üst düzey dışişleri heyetleri arasında diyalog konularından biri olarak görülmesine neden olmuştur. Başka bir deyişle, "diplomasi turizme dayalıdır" ve bu nedenle uluslararası anlaşma ve anlaşmalarda yerini bulmayı başarmıştır (Jalalpour ve Shojaeifar, 2014 :70) 
Grafik 3: Türkiye' de 1969-2019 Yılları Turizm Gelirlerinin GSYİH İçindeki Payı

Kaynak: https://www.ktb.gov.tr/ alınan verilerle Yazar tarafından oluşturulmuştur.

1982 yılında yürürlüğe giren Turizm Teşvik Kanunu'nun etkisi, sadece toplam turizm gelirlerinde değil, turizm gelirlerinin GSYİH içindeki payında da kendisini göstermiştir. Turizm gelirlerinin GSYİH'e oranının dalgalı bir biçimde seyretmesi, toplam gelirlerin düştügüunü sonucunu vermemektedir. Diğer sektörlerdeki büyüme oranlarının turizm sektöründeki büyüme oranından daha fazla olması, GSYİH içinde turizm sektörünün payının düşmesine neden olmuştur. Kriz dönemlerinde turizm gelirlerinin Türkiye'ye gelir getirici etkisinin olduğu görülmektedir (Şen ve Şit, 2015:37). Türkiye'nin 2007 yılında hazırlanan "2023 Yılı Türkiye Turizm Stratejisi" adlı planı 2000'li yılların önemli turizm politikaları arasındadır. Bu strateji planı çerçevesinde özellikle Türkiye'nin yüksek potansiyel taşıdığı sağlık ve termal turizm alanlarındaki yatırımlar teşvik edilmiştir. Ayrıca alternatif turizme yönelik güçlendirme çalışmalarına hız verilmiştir (T.C. Kültür ve Turizm Bakanlığı, 2007).

\section{Türkiye'de 1970-2019 dönemlerine ait uluslararası ticaret ve uluslararası turizm arasındaki ilişki için ekonometrik analiz}

\section{Araştırmanın amacı, veriler ve yöntemi}

Uluslararası ticaret ve ekonomik büyüme arasındaki ilişki yıllar içinde literatürde geniş bir uygulama alanı bulmasına rağmen turizm ve büyüme ya da ticaret ve turizm hakkında bu söylenemez. Bu nedenle yapılan bu çalışma literatüre katkı sağlayacaktır. Bu çalışmada, Türkiye için uluslararası turizm, uluslararası ticaret arasındaki ilişki için Reel GSYİH, toplam ticaret (ihracat ve ithalat verileri), turizm verileri (turizm gelirleri ve gelen turist sayıları) değişkenleri kullanılmıştır. Çalışmada kullanılan veriler, TÜiK, Dünya Bankası, Kültür ve Turizm Bakanlı̆̆ı ve Merkez Bankasından alınmıştır.

Tablo 1: Değişkenlere Ait Tanımlayıcı İstatistikler

\begin{tabular}{|c|c|c|c|c|}
\hline DEĞIŞKEN & LOG_GELEN_TURIST & LOG_RGDP & LOG_TOPLAM_TICARET & LOG_TURIZM_GELIRI \\
\hline Mean & 15.68436 & 26.76017 & 10.68802 & 7.954372 \\
\hline Median & 15.77618 & 26.75395 & 10.70937 & 8.371242 \\
\hline Maximum & 17.76188 & 27.86364 & 12.90784 & 10.44930 \\
\hline Minimum & 13.45056 & 25.68329 & 7.198931 & 3.600048 \\
\hline Std. Dev. & 1.379037 & 0.635830 & 1.698728 & 2.086721 \\
\hline Sum & 799.9025 & 1364.768 & 545.0889 & 405.6730 \\
\hline Sum Sq. Dev. & 95.08718 & 20.21401 & 144.2839 & 217.7202 \\
\hline Gözlemler & 51 & 51 & 51 & 51 \\
\hline
\end{tabular}

Granger nedensellik analizi yardımıyla ilişkinin test edilmesi için öncelikle verilerin durağanlıklarının sağlanması gerekmektedir. Zaman serisi ile ilgili yapılan analizlerde sahte regresyon problemleri ile karşılaşılmaması adına gerekli olan bu durağanlık sınamaları, bu çalışmada Genişletilmiş Dickey- Fuller (ADF) yöntemi ile ele alınmıştır. Granger nedenselliğin ancak durağan veriler ile yapılması nedeniyle çalışmanın nedensellik analizinde birinci farklara yer verilmiştir. Meydana gelen değişiklerin net olarak görülebilmesi için serilerin doğal logaritmaları alınarak analize dahil edilmiştir. 

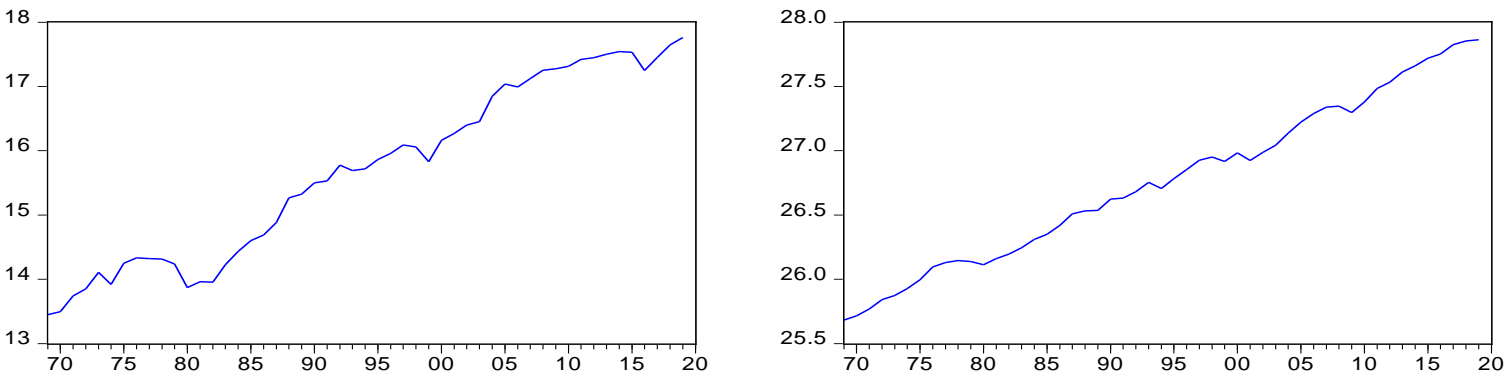

LOG TOPLAM TICARET

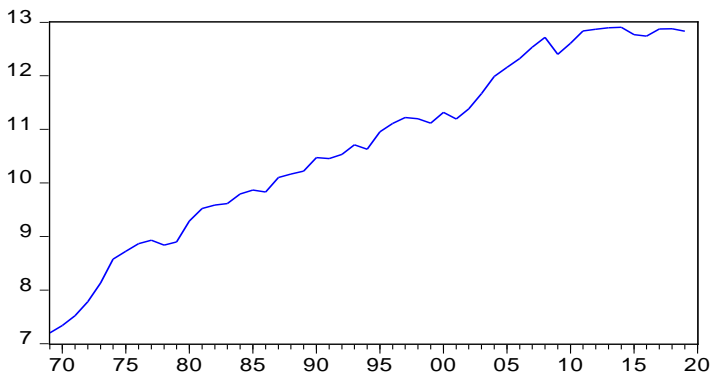

LOG_TURIZM_GELIRI

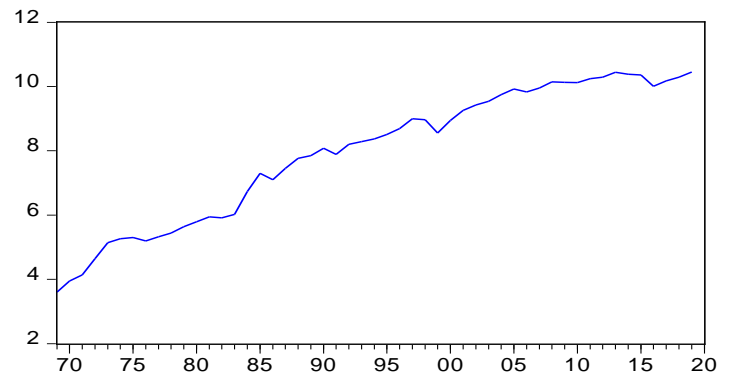

Şekil 1: Durağanlık Öncesi Grafikler

Yukarıda durağanlık öncesi hallerine ait grafikleri verilmiş olan veriler için David A. Dickey ve Wayne A. Fuller (1979)'ın birim köklerin varlığını ve durağanlığını test edilebilen yöntemi kullanılmıştır. Bu yönteme göre;

$$
Y_{t=} p Y_{t-1}+e_{t}
$$

Eşitliğinde Yt gözlenen değeri, $t$ ise zaman endeksini göstermek üzere; $|P| \geq 1$ olduğu gösterilebiliyorsa birim kökün varlı̆̆ından söz edilebilmektedir. Burada $e_{t}$ ise sıfır ortalamalı ve varyanslı bağımsız ve normal dağılımlı rasgele değişkenlerin bir dizisini temsil etmektedir (Dickey ve Fuller, 1979: 427). Dickey ve Fuller tarafından belirtilen hipotezler şu şekildedir; (Gujarati, 2006: 718-719).

H0: $|P| \geq 1$ : Birim kök mevcuttur. Seri durağan değildir.

H1: $|P| \leq 1$ : Birim kök yoktur. Seri durağandır.

Dickey-Fuller testine, kullanılmakta olan değişkenin gecikmeli değerlerinin de eklenmesi ile birlikte oluşturulan Genişletilmiş Dickey-Fuller testi (ADF) ile, hata terimlerindeki korelasyon sorununun çözümü amaçlanmaktadır (Sancar ve Polat, 2015: 422).

\section{Analiz sonuçları}

Aşağıdaki tablo ve grafiklerde yapılan analizin sonuçları yer almaktadır.

Tablo 2: Değişkenlere Ait Durağanlık Sınaması

\begin{tabular}{|c|c|c|c|c|c|c|}
\hline \multirow{2}{*}{ Değişkenler } & \multicolumn{3}{|c|}{ SEVIYE } & \multicolumn{3}{c|}{ BİRINCİ FARK } \\
\cline { 2 - 7 } & $\begin{array}{c}\text { ADF test } \\
\text { İstatistiği }\end{array}$ & $\begin{array}{c}\text { Gecikme } \\
\text { Uzunluğu }\end{array}$ & $\begin{array}{c}\text { \%1 Kritik } \\
\text { değer }\end{array}$ & $\begin{array}{c}\text { ADF test } \\
\text { İstatistiği }\end{array}$ & $\begin{array}{c}\text { Gecikme } \\
\text { Uzunluğu }\end{array}$ & $\begin{array}{c}\text { \%1 Kritik } \\
\text { değer }\end{array}$ \\
\hline log_gelen_turist & -0.627 & 0 & -3.568 & $-3.568^{*}$ & 0 & -3.571 \\
\hline log_rgdp & -0.048 & 0 & -3.568 & $-6.789^{*}$ & 0 & -3.571 \\
\hline log_toplam_ticaret & -2.639 & 0 & -3.568 & $-5.944^{*}$ & 0 & -3.571 \\
\hline log_turizm_geliri & -2.630 & 0 & -3.568 & $-6.250^{*}$ & 0 & -3.571 \\
\hline
\end{tabular}

Not*: Test istatistiğinin \%1 önem düzeyinde anlamlılığını temsil etmektedir. (Gecikme Uzunlukları Schwarz Bilgi Kriteri 'ne göre otomatik belirlenmiştir.

Yukarıdaki tabloda, modelde kullanılan değişkenlere ait durağanlık testleri gösterilmektedir. ADF test istatistiğinin, \%1 kritik değerinden küçük olması durumunda gerçekleşecek olan durağanlık, seviye düzeyinde sağlanamamıştır ancak birinci farklarında durağanlık sağlanmıştır. " $\mathrm{D}$ " sembolü ile gösterilen ve farkları alınmış olan serilerde, Genişletilmiş Dickey-Fuller test istatistik değeri \%1 kritik değerden küçüktür. Bu durumda, H1 kabul edilir. Yani, kullanılacak değişkenler birinci derecelerinde durağandır. Durağan olan serilerin grafikleri aşağıda gösterilmiştir. 

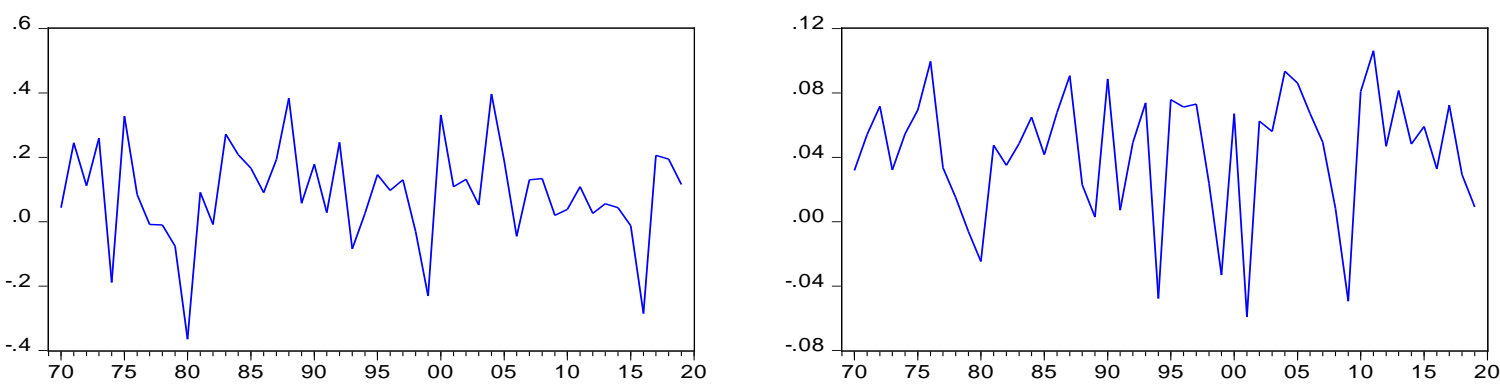

DTOPLAM_TICARET
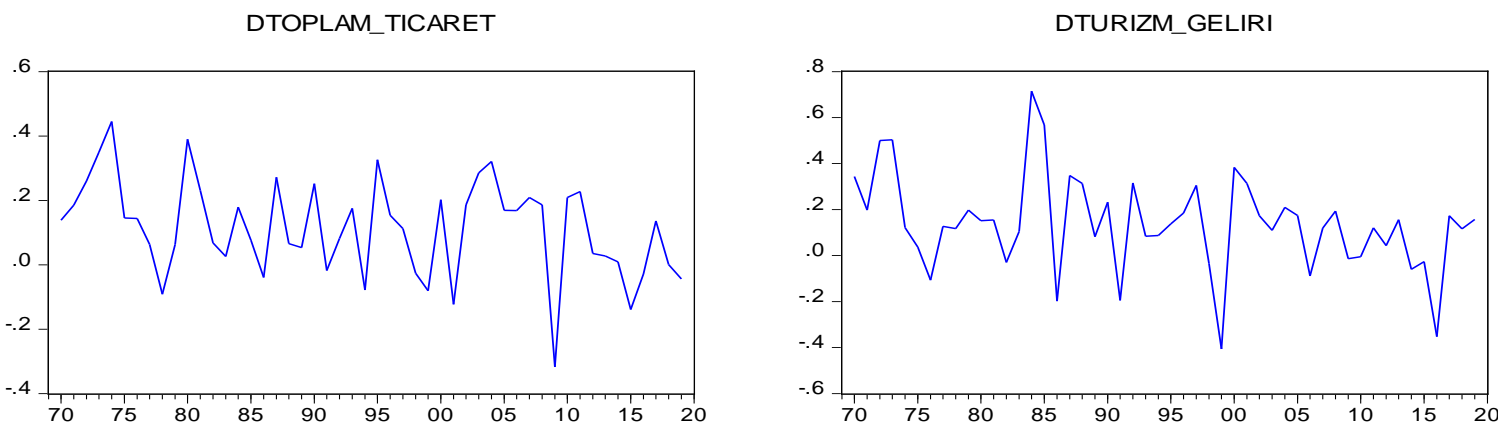

Grafik 4: Durağanlaştırılan Verilere Ait Grafikler

Aşağıda Grafik 5 'te durağan verilere ait grafiklerin birlikte gösterimi yer almaktadır.

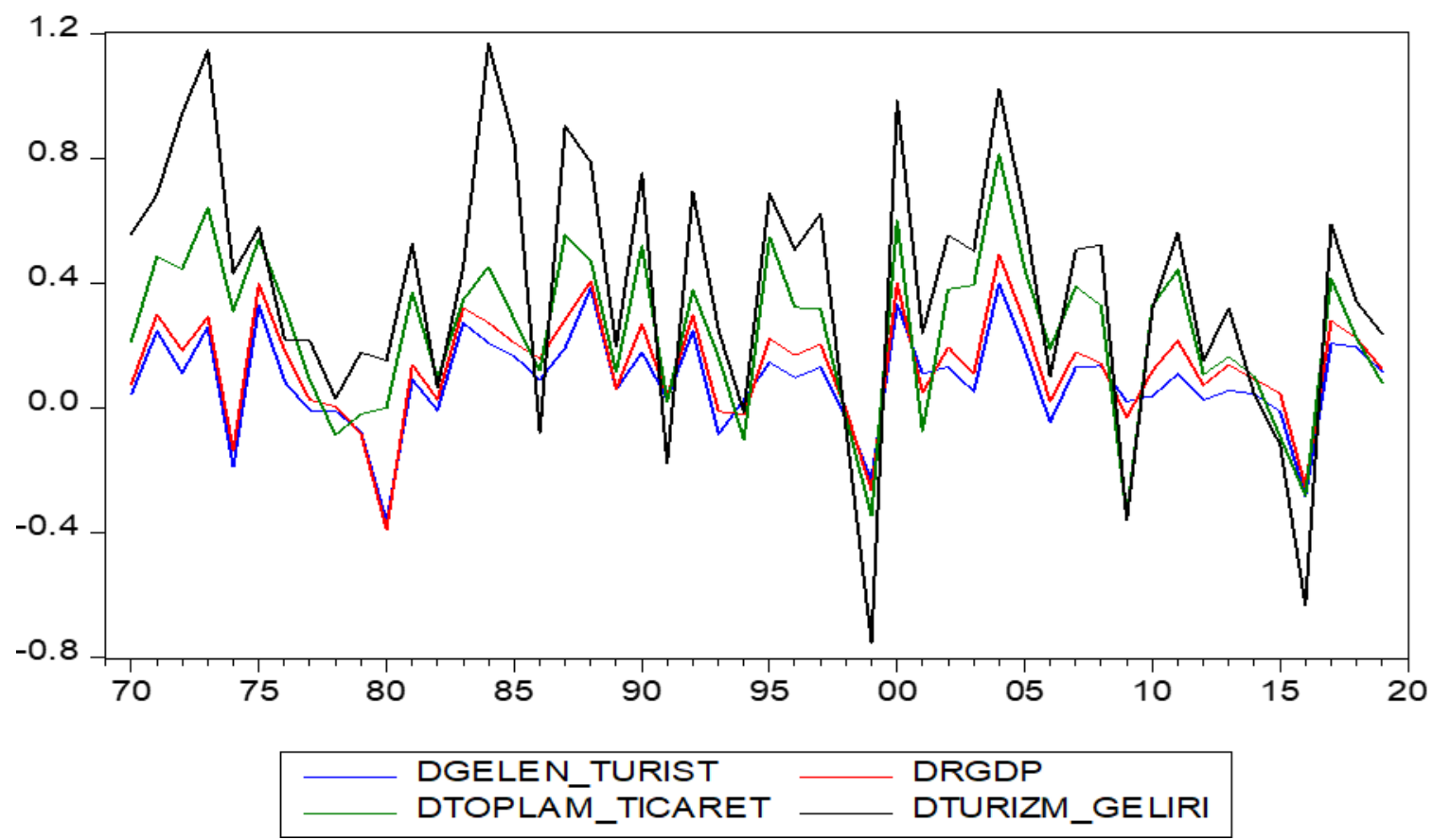

Grafik 5: Durağan Verilere Ait Grafiklerin Birlikte Gösterimi

İki değişken eğer eşbütünleşik ise bu değişkenler arasında uzun dönemli bir ilişki ortaya çıkabilir. Granger, iki seri eşbütünleşik ise bu seriler arasında en az bir yönde bir nedensellik ilişkisi olması gerektiğini belirtmektedir. Değişkenler arasında bir nedenselliğin varlığının araştırılması ve var olan nedenselliklerin yönü ile ilgili olarak birtakım sonuçlara ulaşmak için Granger yöntemi kullanılmaktadır. Bu test birtakım eşitlikleri sınayarak nedenselliği araştırmaktadır. Bu eşitlikler şunlardır (Granger, 1969: 431):

$$
X_{t}=\sum_{i=1}^{m} a_{i} X_{t-i}+\sum_{i=1}^{m} b_{i} Y_{t-i}+\varepsilon_{t 1}
$$




$$
Y_{t}=\sum_{i=1}^{m} c_{i} X_{t-i}+\sum_{i=1}^{m} d_{i} Y_{t-i}+\varepsilon_{t 2}
$$

Verilen denklemlerde $a_{i}, b_{i}, c_{i}$, ve $d_{i}$ gecikme katsayılarını ifade ederken, $m$ ifadesi bütün değişkenler için ortak olan gecikme derecesini, $\varepsilon_{t 1}$ ve $\varepsilon_{t 2}$ ise korelasyona sahip olmayan süreçleri ifade etmektedir (Uzunöz ve Akçay, 2012: 8).

Tablo 4: Uygun Gecikme Uzunluğunun Belirlenmesi

\begin{tabular}{|c|c|c|c|c|c|c|}
\hline Lag & LogL & LR & FPE & AIC & SC & HQ \\
\hline 0 & 145.2607 & NA $^{*}$ & $1.20 \mathrm{e}-08$ & -6.890766 & $-6.723588^{*}$ & -6.829889 \\
\hline 1 & 156.2658 & 19.32596 & $1.53 \mathrm{e}-08$ & -6.647110 & -5.811221 & -6.342726 \\
\hline 2 & 162.8860 & 10.33406 & $2.48 \mathrm{e}-08$ & -6.189562 & -4.684962 & -5.641669 \\
\hline 3 & 175.0530 & 16.61830 & $3.18 \mathrm{e}-08$ & -6.002585 & -3.829274 & -5.211185 \\
\hline 4 & 185.9960 & 12.81130 & $4.60 \mathrm{e}-08$ & -5.755901 & -2.913879 & -4.720993 \\
\hline 5 & 208.8516 & 22.29822 & $4.08 \mathrm{e}-08$ & -6.090324 & -2.579591 & -4.811909 \\
\hline 6 & 223.2855 & 11.26548 & $6.33 \mathrm{e}-08$ & -6.013929 & -1.834485 & -4.492006 \\
\hline 7 & 252.2030 & 16.92732 & $6.18 \mathrm{e}-08$ & -6.644051 & -1.795896 & -4.878620 \\
\hline 8 & 302.1837 & 19.50464 & $3.41 \mathrm{e}-08$ & -8.301643 & -2.784777 & -6.292705 \\
\hline $\mathbf{9}$ & $\mathbf{4 1 2 . 1 5 3 9}$ & $\mathbf{2 1 . 4 5 7 6 1}$ & $\mathbf{3 . 1 5 e - 0 9 *}$ & $\mathbf{- 1 2 . 8 8 5 5 6 *}$ & $-\mathbf{- 6 . 6 9 9 9 8 0}$ & $\mathbf{- 1 0 . 6 3 3 1 1 ^ { * }}$ \\
\hline
\end{tabular}

Not: AIC: Akaike, SC: Schwarz, HQ: Hannan-Quinn bilgi kriterlerini temsil etmektedir. Uygun gecikme uzunluğu $\left(^{*}\right)$ sembolü ile ifade edilmiştir.

Granger nedensellik analizinin gecikme uzunluğuna duyarlı olduğu bilinmektedir. Uygunluk için Akaike, Schwarz ve Hannan-Quinn Bilgi kriterleri dikkate alınmıştır. Türkiye için uygun gecikme değeri 9 olarak belirlenmiştir.

Tablo 5: Granger Nedensellik Analizine Ait Çıtılar

\begin{tabular}{|c|c|c|c|c|}
\hline Bağımlı Değişken & Bağımsız Değişkenler & $\begin{array}{l}\text { Gecikme } \\
\text { Uzunluğu }\end{array}$ & Prob. Değeri & SONUÇ \\
\hline \multirow{3}{*}{ DGELEN_TURIST } & DRGDP & 9 & 0.8989 & $\mathrm{H}_{0}$ Reddedilemez \\
\hline & DTOPLAM_TICARET & 9 & 0.9379 & $\mathrm{H}_{0}$ Reddedilemez \\
\hline & DTURIZM_GELIRI & 9 & 0.8614 & $\mathrm{H}_{0}$ Reddedilemez \\
\hline \multirow{3}{*}{ DRGDP } & DGELEN_TURIST & 9 & 0.7246 & $\mathrm{H}_{0}$ Reddedilemez \\
\hline & DTOPLAM_TICARET & 9 & 0.9143 & $\mathrm{H}_{0}$ Reddedilemez \\
\hline & DTURIZM_GELIRI & 9 & 0.5082 & $\mathrm{H}_{0}$ Reddedilemez \\
\hline \multirow{3}{*}{ DTOPLAM_TICARET } & DGELEN_TURIST & 9 & 0.6104 & $\mathrm{H}_{0}$ Reddedilemez \\
\hline & DRGDP & 9 & 0.5925 & $\mathrm{H}_{0}$ Reddedilemez \\
\hline & DTURIZM_GELIRI & 9 & 0.5086 & $\mathrm{H}_{0}$ Reddedilemez \\
\hline \multirow{3}{*}{ DTURIZM_GELIRI } & DGELEN_TURIST & 9 & 0.0000 & $\mathrm{H}_{1}$ KABUL \\
\hline & DRGDP & 9 & 0.0013 & $\mathrm{H}_{1}$ KABUL \\
\hline & DTOPLAM_TICARET & 9 & 0.0001 & H$_{1}$ KABUL \\
\hline
\end{tabular}

Aşağıda Şekil 2'de kabul edilen nedensellikler ve bu nedenselliklerin yönü ok işaretleri ile gösterilmiştir. Toplam ticaret (ithalat ve ihracat akışları), turist girişleri ve Reel GSYIH'dan turizim gelirine uzanan tek yönlü bir nedensellik olduğu sonucuna varılmıştır. 


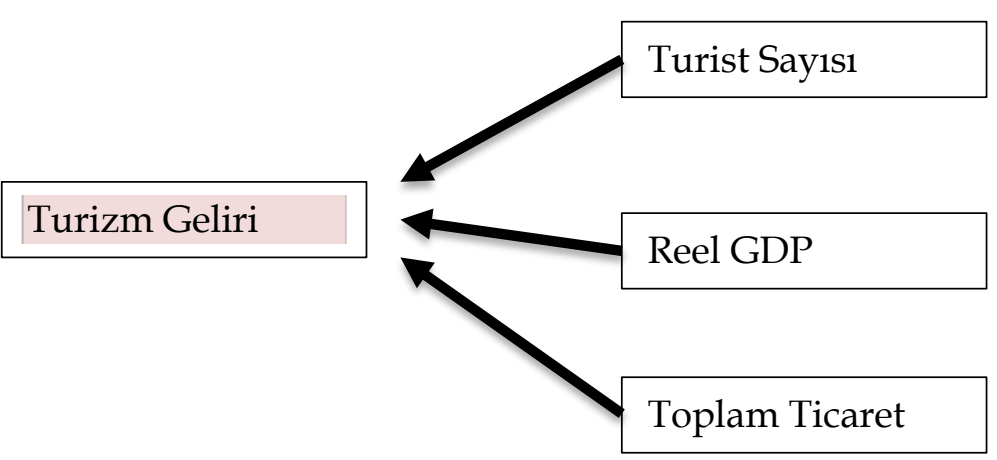

\section{Şekil 1: Nedensellik Analizi Sonuçlarının Gösterimi}

Aralarında nedensellik ilişkisi bulunan değişkenlerin uzun dönemli ilişkilerinin incelenmesi için ise Engle Granger eşbütünleşme testi uygulanmıştır. İki aşamadan oluşan bu yöntemde; aynı seviyede durağanlaşmış serilerin seviye değerleri ile kurulan regresyon modelinden elde edilmiş olan kalıntıların durağanlığı incelenmektedir. Eğer bu kalıntılar seviye değerlerinde durağan iseler, uzun dönemde birlikte hareket ederler, yani seriler eşbütünleşiktir. Aralarında Granger nedenselliği bulunmuş olan değişkenlere ait eşbütünleşme testi sonuçları Tablo $6^{\prime}$ da gösterilmiştir.

Tablo 6: Engle-Granger Eşbütünleşme Analizi

\begin{tabular}{|c|c|c|}
\hline \multicolumn{3}{|c|}{ Seviye } \\
\hline & $\mathbf{t}$ İstatistiği & Prob \\
\hline Sabitli & -6.541384 & $0.0000^{*}$ \\
\hline Sabitli ve Trendli & -6.571141 & $0.0001^{*}$ \\
\hline Sabitsiz ve Trendsiz & -6.607238 & $0.0000^{*}$ \\
\hline
\end{tabular}

Not: * \%1 anlamlılık düzeyinde anlamlılı̆̆ ifade etmektedir.

Verilen şekilden de anlaşılacağı üzere modellere ait hata terimlerinin $\mathrm{p}$ olasılık değeri $0.05^{\prime}$ ten küçüktür, yani değişkenler eşbütünleşiktir. Kısa dönemli olarak elde edilen toplam ticaret, reel GSYİH ve turist sayılarından turizm gelirlerine doğru olan nedenselliğin uzun dönem geçerliliği EngleGranger eşbütünleşme testi ile sınanmıştır. Yapılan analiz sonucu serilerin eşbütünleşik olduğu, uzun dönemde birlikte hareket ettikleri sonucuna ulaşılmıştır.

\section{Sonuç ve öneriler}

Turizm, toplulukları ve ülkeleri küresel piyasa ekonomisine entegre etmede önemli bir yere sahiptir. Dünyadaki çoğu ülke artık kültürlerini, toplumlarını ve doğal çevrelerini turistlere yönelik olarak kullanıma açmaktadır. Turizmin bir ülke için sürdürülebilir olması önemlidir. Turizm ekonomileri desteklemekten ve istihdam olanakları sağlamaktan çok dünyaya daha fazla katkıda bulunmaktadır.

Bu çalışmada Türkiye için seçilen yıl aralığı olan 1970-2019 dönemi için belirlenen değişkenler ışığında (Reel GSYİH, toplam ticaret ve turizm verileri) kullanılarak yapılan analiz sonucunda uluslararası ticaret ve uluslararası turizm arasında ilişki olduğu görülmüştür. Çalışma sonuçlarına göre Türkiye'de belirlenen dönemlerde uluslararası turizm, uluslararası ticaretin Granger nedenidir. Çalışma kapsamında bulunan sonuçların uzun dönemli olarak geçerliliği Engle-Granger Eşbütünleşme analizi yardımı ile sınanmış ve uzun dönemli ilişkinin olduğu sonucuna varılmıştır. Türkiye' ye gelen turist sayılarına bakıldığında ülkenin turistleri çekme konusunda çalışmada gösterilen grafiklerde de görüleceği üzre başarılı olduğunu dolayısıyla da Türkiye'nin turizm ülkesi olduğunu belirtmek mümkündür. Ayrıca turizm gelirlerinin Türkiye'nin makroekonomik sorunlarınada (ödemeler bilançosu açıkları) çözüm getirmede önemli bir faktör olacağı söylenebilir. Bunlara ilaveten turizm gelirlerinin Türkiye ekonomisinin büyümesi açısından önemine yönelik göstergesi olarak kabul edilebilir olan GSYİH içindeki payının arttığı hatta kriz dönemlerinde bile gelir sağlayıcı etkisinin olduğu görülmüştür. Dolayısıyla turizmin Türkiye açısından önemli bir ticaret faaliyeti ve ülkeye birçok yönden katkısının olduğunu söyleyebiliriz. Dünyada uluslararası ilişkiler bakımından iyileşmelerin sağlanması adına turizm aracı bir faktör olarak görülebilir. Çünkü turizm, dünyayı etkileme potansiyeline sahiptir. Turizm sayesinde hem kamu diplomasisini hem de uluslararası alanda ekonomik ilişkileri geliştirmek mümkün olacaktır. Turizm endüstrisinin boyutlarının hükümetlerin politikalarına bağlı olması hükümetlerin bu endüstri için alacağı kararların diğer ülkelerle arasındaki ilişkileri etkileyeceği muhakkaktır. Çünkü bu endüstri, ekonomik büyüme ve kalkınmanın yanı sıra siyasi gelişme ve barışın genişlemesinde çok önemli bir rol oynamaktadır. Türkiye'nin coğrafi konumu nedeniyle turist çekme gücüne sahip olma özelliğini kullanarak turistleri çekebilmek adına ulaşım 
kolaylıklarını sağlaması, uluslararası anlaşmalar yaparak diğer ülkelerle arasındaki iş politikalarını güçlendirmesi, ulusal ve uluslararası etkinliklerini artırmaya yönelik faaliyetlere yönelik hükümet kararları alması oldukça önemlidir. Kısacası uluslararası akışları engelleyen engeller azaltılmalı ya da kontrollü bir şekilde kaldırılmalıdır.

\section{Hakem Değerlendirmesi / Peer-review:}

Diş bağımsız

Externally peer-reviewed

\section{Çıkar Çatışması / Conflict of interests:}

Yazar(lar) çıkar çatışması bildirmemiştir.

The author(s) has (have) no conflict of interest to declare.

\section{Finansal Destek / Grant Support:}

Yazar bu çalışma için finansal destek almadığını beyan etmiştir.

The author declared that this study has received no financial support.

\section{Kaynakça / References}

Altıntaş, A., \& Şahin, F.K. (2007). Reşit Saffet Atabinen (1884-1965) ve Türk turizmine katkıları, 9-36. http:// dergiler.ankara.edu.tr/dergiler/18/831/10496.pdf

Aradhyula, S., \& Tronstad, R. (2003). Does tourism promote cross-border trade?. American Journal of Agricultural Economics, 85 (3), 569-579. https:// doi.org/10.1111/1467-8276.00456

Bahar, O., \& Baldemir, E. (2008). Uluslararası ticaret ile uluslararası turizm arasındaki nedensellik ilişkisi: Türkiye örneği. Dokuz Eylül Üniversitesi Sosyal Bilimler Enstitüsü Dergisi, 10(4), 97-111.

Berno, T., \& Bricker, K. (2001). Sustainable tourism development: the long road from theory to practice. International Journal of Economic Development, 3(3), 1-18.

Çelik, K. (2004). Uluslararası İktisat. 1. Baskı, Trabzon: Derya Kitabevi.

Çoban, O. , \& Özcan, C. C. (2013). Türkiye'de turizm gelirleri-ekonomik büyüme ilişkisi: nedensellik analizi (1963-2010). Eskişehir Osmangazi Üniversitesi İ̈BF Dergisi, 8(1), 243 - 261.

Dickey, D.A., \& Fuller, W.A. (1979). Distribution of the estimators for autoregressive time series with a unit root. Journal of the American Statical Association, 74(366), 427-431.

Dritsakis, N., \& Athanasiadis, S. (2000). An econometric model of tourist demand: the case of Greece. Journal of Hospitality \& Leisure Marketing, 7(2), 39-49.

Fry, D., Saayman, A., \& Saayman, M. (2010). The relationship between tourism and trade in South Africa. South African Journal of Economics, 78(3), 287-306.

Granger, C.W.J.(1969). Investigating causal relations by econometric models and cross-spectral methods, Econometrica, 37 (3), 424-438.

Gujarati, D. N. (2006). Temel ekonometri. (Çev: Ü. Şenesen ve G.G. Şenesen), İstanbul: Literatür Yayınları.

Hanafiah, M.H., \& Zulkifly, M.I. (2019). The evolution of tourism destination competitiveness (TDC) models. IGI Global. 23-48.

https:/ / data.worldbank.org/indicator/NY.GDP.PCAP.CD?end=2019\&locations=DE\&start=1970\&vie $\mathrm{w}=$ chart $(10.05 .2021)$

https: / / data. worldbank.org/indicator/SP.POP.TOTL?end=2019\&locations=DE\&start=2010\&view=ch art (10.05.2021)

https://evds2.tcmb.gov.tr/index.php?/evds/serieMarket/\#collapse_28 (21.05.2021). 
https://www.tursab.org.tr/turkiye-turizm-degerlendirmesi/turizmin-ekonomideki-yeri ( 27.06.2021) https://yigm.ktb.gov.tr/TR-201116/turizm-gelirleri-ve-giderleri.html (25.06.2021).

Jalalpour, S., \& Shojaeifar, J. (2014). The tourism industry and the international relations. World Journal of Environmental Biosciences, 6, 68-72.

Kadir, N., \& Jusoff, K. (2010). The cointegration and causality tests for tourism and trade in Malaysia. International Research Journal of Finance and Economics, 2(1), 138-143.

Kanca, O. C. (2015). Turizm gelirleri ve ekonomik büyüme (1980 - 2013). Marmara Sosyal Araştırmalar Dergisi, 8, 1 - 14 .

Katırcıoğlu, S. T. (2009). Tourism, trade and growth: the case of Cyprus. Applied Economics, 41, 27412750.

Kulendran, N., \& Wilson, K. (2000). Is there a relationship between international trade and international arrivals?. Applied Economics, 32(8), 1001-1009.

Kyrylov, Y., Hranovska, V., Boiko, V., Kwilinski, A., \& Boiko, L. (2020). International tourism development in the context of increasing globalization risks: on the example of Ukraine's integration into the global tourism industry. Journal of Risk Financial Management, 13(12), 1-18. https://doi.org/10.3390/jrfm13120303

Lim, C., \& McAleer, M. (2000). A seasonal analysis of Asian tourist arrivals to Australia. Applied Economics, 32(4), 499-509, DOI: 10.1080/000368400322660

Luca, E. (1997). International tourism: a global perspective, (Eds: Chuck Y. Gee and Eduardo FayosSolá), Introduction to global tourism learning objectives. 1. Bask1, Published By The World Tourism Organization, Madrid: Spain, Isbn: 92-844-0231-X.

Majewska , J., \& Mińska-Struzik, E. (2012). In search of the relationship between international tourism and trade: evidence from Poland. Poland: Poznan University of Economics, 1-27.

Massidda, C., \& Mattana, P. (2013). A SVECM analysis of the relationship between international tourism arrivals, GDP and trade in Italy. Journal of Travel Research, 52(1), 93-105.

Ozcan, C. C.,\& Ozcan, G. (2020). Economic and social impact of mass tourism developments in Turkey: A theoretical assessment. Journal of Travel and Tourism Research, (15), 1-26.

Ozcan, C.C.(2016). International trade and tourism for Mediterranean countries: A panel causality analysis. Theoretical and Applied Economics, 1(606), 203-212.

Önen, O. (2000). Türkiye'nin turizm sektöründeki gelişmeler, dünya turizmindeki yeri ve Türkiye Kalkınma Bankası'nın rolü. Ankara: Türkiye Kalkınma Bankası A.Ş.

Özcan, C., \& Yorgancılar, F. N. (2016). Uluslararası ticaret ve turizm arasında bir ilişki var mı? . Yönetim ve Ekonomi Araştırmaları Dergisi, 14 (1) , 37-48.

Sancar, C., \& Polat, M.A. ( 2015). Türkiye'de ekonomik büyüme, enerji tüketimi ve ithalat ilişkisi. Gümüşhane Üniversitesi Sosyal Bilimler Elektronik Dergisi, 6 (12), 416-432.

Seyidoğlu, H. (2007). Uluslararası iktisat teori politika ve uygulamaları. 16. Baskı, İstanbul: Güzem Yayınları.

Shan, J., \& Wilson, K. (2001). Causality between trade and tourism: empirical evidence from China. Applied Economic Letters, 8 (4), 279-283. https:/ / doi.org/10.1080/135048501750104114

Şen, A., \& Şit, M. (2015). Turizm gelirlerinin Türkiye ekonomisindeki rolü ve önemi. Dicle Üniversitesi İktisadi ve İdari Bilimler Fakültesi Dergisi, 5 (8), 30-45.

T.C. Kültür ve Turizm Bakanlığı (2007). Türkiye turizm stratejisi 2023 eylem planı 2007-2013, Ankara: $\begin{array}{lllll}\text { T.C. Kültür } & \text { ve }\end{array}$ https://www.ktb.gov.tr/Eklenti/906,ttstratejisi2023pdf.pdf?0.

T.C. Kültür ve Turizm Bakanlığı,Turizm İstatistikleri, (2021). Erişim adresi: https://yigm.ktb.gov.tr/TR-9851/turizm-istatistikleri.html

Toker, B. (2007). Türkiye'de turizm sektörü teşviklerinin değerlendirilmesi. Yönetim ve Ekonomi Dergisi, 14(2), 81 - 92. 
Türkiye İstatistik Kurumu (TÜIK), Turizm İstatistikleri, (2021). Erişim adresi: https://data.tuik.gov.tr/Kategori/GetKategori?p=Egitim,-Kultur,-Spor-ve-Turizm-105

Uzunöz, M., \& Akçay , Y. (2012). Türkiye' de büyüme ve enerji tüketimi arasındaki nedensellik ilişkisi: 1970-2010. Çankırı Karatekin Üniversitesi Sosyal Bilimler Enstitüsü Dergisi, 3 (2), 1-16.

Wang, K-L.,\& Wu, C-S. (2003). Trade-in services in the Asia Pacific Region. (Eds: Takatoshı Ito \& Anne O. Krueger) Chapter 12: A Study of Competitiveness of International Tourism in The Southeast Asian Region, University of Chicago Press, 315-346. ISBN: 0-226-38677-5. 